\title{
Identification of dihydropyrazine-glutathione adducts
}

\author{
Shinji Takechi', Shigeru Ito², Nobuhiro Kashige ${ }^{3}$, Takumi Ishida ${ }^{1}$ \\ and Tadatoshi Yamaguchi ${ }^{1}$ \\ ${ }^{1}$ Faculty of Pharmaceutical Sciences, Sojo University, Ikeda 4-22-1, Kumamoto 860-0082, Japan \\ ${ }^{2}$ Institute of Biomaterials and Bioengineering, Tokyo Medical and Dental University, Tokyo 101-0062, Japan \\ ${ }^{3}$ Faculty of Pharmaceutical Sciences, Fukuoka University, Fukuoka 814-0180, Japan
}

(Received January 30, 2015; Accepted May 19, 2015)

\begin{abstract}
Dihydropyrazines (DHPs) are glycation intermediates generated both in vivo and in food. DHPs can lead to the formation of a variety of different radical species, which can lead to DNA damage and enzyme inhibition. In addition, the presence of DHPs can lead to a decrease in cellular glutathione (GSH) levels, and induce the expression of antioxidant genes. In this study, the products resulting from the reaction of DHP with GSH have been analyzed in detail, with some of the products being separated by reversed-phase HPLC. The structures of the isolated DHP-GSH adducts were determined by FAB-MS and NMR analyses. These data suggested that the reaction of DHP with a thiol moiety could be involved in oxidative stress, because an increase in the amount of DHP-GSH adducts would result in a decrease in the cellular GSH levels.
\end{abstract}

Key words: Dihydropyrazine, Glutathione, Adduct, Oxidative stress, FAB-MS, NMR

\section{INTRODUCTION}

Dihydropyrazines (DHPs), which are formed by nonenzymatic glycation, have been reported to generate various radicals and reactive oxygen species (ROS) that are capable of causing DNA strand cleavage in vitro (Yamaguchi et al., 1996). DHPs are presumed to be precursors of pyrazines, which can have an adverse impact on human health. Many pyrazine derivatives, which are produced as the metabolites of DHPs, have been found in human urine (Zlatkis et al., 1973). 5-Aminolevulinic acid (ALA) is a heme precursor that accumulates in lead poisoning and inborn porphyrias, and the condensation of two molecules of ALA leads to the formation of the DHP derivative, 3,6dihydropyrazine-2,5-dipropanoic acid, which has been reported to exhibit DNA strand-cleaving activity in vitro (Teixeira et al., 2001). Despite concerns surrounding the effects of DHPs on human health, there is very little evidence in the literature regarding a causal relationship between DHP and disease. We previously reported that DHP causes greater growth inhibition in GSH-deficient bacteria than it does in GSH-sufficient bacteria (Takechi et al., 2011), and we also observed a significant decrease in the ratio of intracellular reduced glutathione and oxidized glutathione (GSH/GSSG) in DHP-exposed cultured cell (Ishida et al., 2012). In the current study, we have identified novel DHP-GSH adducts from the reaction products of DHP with GSH. The findings of this study suggest that DHP is effectively enforcing cellular stress by the depletion of cellular GSH levels.

\section{MATERIALS AND METHODS}

\section{General experimental procedures}

${ }^{1} \mathrm{H}$ and $13 \mathrm{C}$ NMR spectra were recorded at 500 and $125 \mathrm{MHz}$, respectively, on a Bruker AVANCE spectrometer (Bruker, Billerica, MA, USA) at $298 \mathrm{~K}$ using a DCH Cryo-probe. The spectra were measured in $\mathrm{CD}_{3} \mathrm{OD}$ in all cases, and the residual solvent peak ( $\delta 3.30 \mathrm{ppm})$ was used as an internal reference standard for reporting the chemical shifts. ${ }^{1} \mathrm{H}-1 \mathrm{H}$ COSY (correlation spectroscopy), phase sensitive nuclear overhauser enhancement spectroscopy (NOESY), ${ }^{1} \mathrm{H}$-detected heteronuclear single-bond quantum correlation (HSQC) and ${ }^{1} \mathrm{H}$-detected heteronuclear multiple bond correlation (HMBC) experiments were carried out on the same instrument. Fast atom bombardment-mass spectrometry (FAB-MS) experiments using $m$-nitrobenzyl alcohol as a matrix were conducted on a JEOL JMS-HX110 double-focusing model (JEOL, Tokyo, Japan) equipped with a FAB ion source interfaced

Correspondence: Shinji Takechi (E-mail: stakechi@ph.sojo-u.ac.jp) 
with a JEOL JMA-DA 700 data system. High-resolution mass spectrometry (HRMS) experiments were obtained using the same mass spectrometer.

\section{Synthesis of DHP derivatives}

3-Hydro-2,2,5,6-tetramethylpyrazine (Me-DHP-3) and Cyclohexyl-DHP (Fig. 1), as well as a mixture of the two isomers of 2,3,5,6,7,8-hexahydroquinoxaline (endotype) and 1,2,3,5,6,7-hexahydroquinoxaline (exo-type), were prepared using a previously reported procedure (Yamaguchi et al., 1998).

\section{Reaction and isolation procedure of Adducts P1, P2, P3}

A reaction mixture containing $50 \mathrm{mM}$ DHP and $50 \mathrm{mM}$ GSH was incubated in $0.1 \mathrm{M}$ sodium phosphate buffer $(\mathrm{pH} 7)$ at $37^{\circ} \mathrm{C}$ for $24 \mathrm{hr}$, and the resulting reaction products were separated by reversed-phase HPLC using a Chromolith SemiPrep RP-18e column $(10 \times 100 \mathrm{~mm}$; Merck, Darmstadt, Germany), which was equilibrated with a mobile phase consisting of 5\% methanol in an aqueous solution of $0.1 \%$ trifluoroacetic acid at a flow rate of $3 \mathrm{~mL} / \mathrm{min}$. The elution profiles were monitored by absorbance at $210 \mathrm{~nm}$ (Fig. $2 \mathrm{~A}$ ).

\section{(Z)-2-amino-5-((1-((carboxymethyl)amino)-} 1-oxo-3-(((3,6,6-trimethyl-5,6-dihydropyrazin2(1H)-ylidene)methyl)thio)propan-2-yl)amino)5-oxopentanoic acid (P1)

HRMS-FAB-MS in the positive ionization mode gave $m / z$ : 444.1916 (Calcd for $\mathrm{C}_{18} \mathrm{H}_{30} \mathrm{~N}_{5} \mathrm{O}_{6} \mathrm{~S}[\mathrm{M}+\mathrm{H}]^{+}$:
444.1917). ${ }^{1} \mathrm{H}$ NMR: $\delta 7.31$ (s, 1H), $4.75(\mathrm{dd}, J=8.1,5.3$ $\mathrm{Hz}, 1 \mathrm{H}), 3.92$ (dd, $J=26.6,17.7 \mathrm{~Hz}, 2 \mathrm{H}), 3.68$ (d, $J=6.7$ $\mathrm{Hz}, 1 \mathrm{H}), 3.54$ (dd, $J=14.1,5.3 \mathrm{~Hz}, 1 \mathrm{H}, \mathrm{Cys}-\beta) \& 3.30^{* 1}$, 3.47 (s, 2H), $2.54(\mathrm{~m}, 2 \mathrm{H}), 2.53(\mathrm{~s}, 3 \mathrm{H}), 2.14(\mathrm{~m}, 2 \mathrm{H})$, 1.24 (s, 6H). ${ }^{13} \mathrm{C}$ NMR: $\delta 174.9\left(\mathrm{CO}_{2}\right), 173.3(\mathrm{CO}), 172.8$ $\left(\mathrm{CO}_{2}\right), 172.1(\mathrm{CO}), 167.2(\mathrm{C})^{* 2}, 132.0(\mathrm{CH}), 131.86(\mathrm{C})$, $54.9(\mathrm{CH}), 54.82\left(\mathrm{CH}_{2}\right), 54.76(\mathrm{CH}), 48.4(\mathrm{C}) * 2,42.0$ $\left(\mathrm{CH}_{2}\right), 37.2\left(\mathrm{CH}_{2}\right)^{*}, 32.8\left(\mathrm{CH}_{2}\right), 27.6\left(\mathrm{CH}_{2}\right), 26.0\left(\mathrm{CH}_{3}\right)$, $18.5\left(\mathrm{CH}_{3}\right) .{ }^{* 1}$ One of the germinal $\beta$-methylene protons of cysteine was concealed behind a broad solvent signal at $\delta 3.30 \mathrm{ppm}$, but its ${ }^{1} J_{\mathrm{H} / \mathrm{C}}$ correlation with the corresponding $\beta$-carbon of cysteine was observed in the HSQC spectrum. ${ }^{*}$ Two quaternary carbons were not observed in the ${ }^{13} \mathrm{C}$ NMR spectrum, but the HMBC spectrum clearly showed ${ }^{3} J_{\mathrm{H} / \mathrm{C}}$ long range correlations from $\delta_{\mathrm{H}} 7.31$ and $3.47 \mathrm{ppm}$ to $\delta \mathrm{c} 167.2 \mathrm{ppm}$, as well as ${ }^{2} J_{\mathrm{H} / \mathrm{C}}$ correlations from $\delta_{\mathrm{H}} 1.24$ and $3.47 \mathrm{ppm}$ to $\delta \mathrm{c} 48.4 \mathrm{ppm}$.

\section{(Z)-2-amino-5-((1-((carboxymethyl)amino)- 1-oxo-3-(((3,5,5-trimethyl-5,6-dihydropyrazin- 2(1H)-ylidene)methyl)thio)propan-2-yl)amino)- 5-oxopentanoic acid (P2)}

HRMS-FAB-MS in the positive ionization mode gave $m / z$ : 444.1917 (Calcd for $\mathrm{C}_{18} \mathrm{H}_{30} \mathrm{~N}_{5} \mathrm{O}_{6} \mathrm{~S}[\mathrm{M}+\mathrm{H}]^{+}$: 444.1917). ${ }^{1} \mathrm{H}$ NMR: $\delta 7.25$ (s, 1H), $4.74(\mathrm{dd}, J=7.8,5.8$ $\mathrm{Hz}, 1 \mathrm{H}), 3.96(\mathrm{dd}, J=27.8,17.7 \mathrm{~Hz}, 2 \mathrm{H}), 3.95(\mathrm{~d}, J=5.7$ $\mathrm{Hz}, 1 \mathrm{H}), 3.52$ (dd, $J=14.1,5.8 \mathrm{~Hz}, 1 \mathrm{H}, \mathrm{Cys}-\beta)$ \& 3.29*, $3.08(\mathrm{~s}, 2 \mathrm{H}), 2.56(\mathrm{dd}, J=14.0,7.3 \mathrm{~Hz}, 2 \mathrm{H}), 2.48(\mathrm{~s}, 3 \mathrm{H})$, $2.17(\mathrm{~m}, 2 \mathrm{H}), 1.40(\mathrm{~s}, 6 \mathrm{H}) .{ }^{13} \mathrm{C} \mathrm{NMR}: \delta 174.4(\mathrm{CO}), 172.6$ $\left(\mathrm{CO}_{2}\right), 172.0\left(\mathrm{CO}_{2}\right), 171.9(\mathrm{CO}), 166.3(\mathrm{C}), 132.1(\mathrm{C})$, $130.1(\mathrm{CH}), 56.8(\mathrm{C}), 54.7(\mathrm{CH}), 53.8(\mathrm{CH}), 50.1\left(\mathrm{CH}_{2}\right)$,<smiles>CC1=NCC(C)(C)N=C1C</smiles><smiles>C#CC</smiles>

Me-DHP-3 : 3-hydro-2,2,5,6-tetramethylpyrazine<smiles>C1CCC2=NCCN=C2C1</smiles>

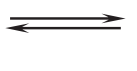<smiles>C1=C2NCCN=C2CCC1</smiles>

Cyclohexyl-DHP : the mixture of 2,3,5,6,7,8-hexahydroquinoxaline (endo-type) and 1,2,3,5,6,7-hexahydroquinoxaline (exo-type)

Fig. 1. Chemical structures of the DHP derivatives used in this Study. 
The adducts of dihydropyrazine and glutathione

A

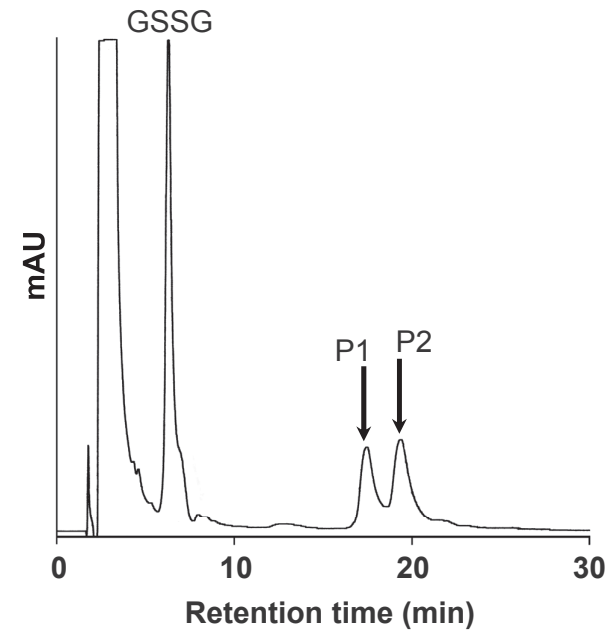

B
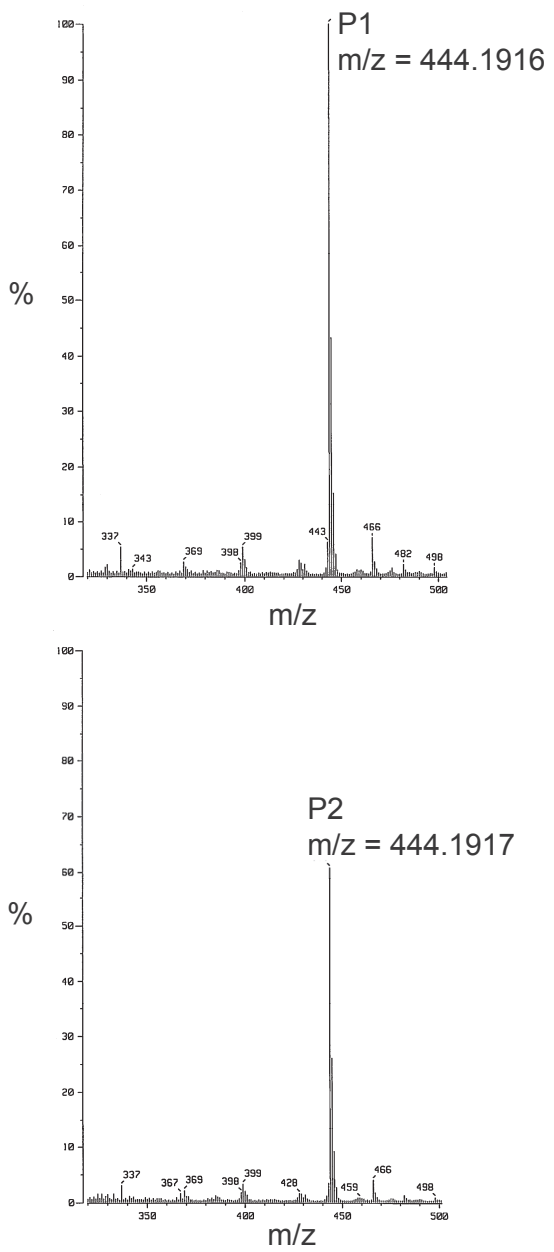
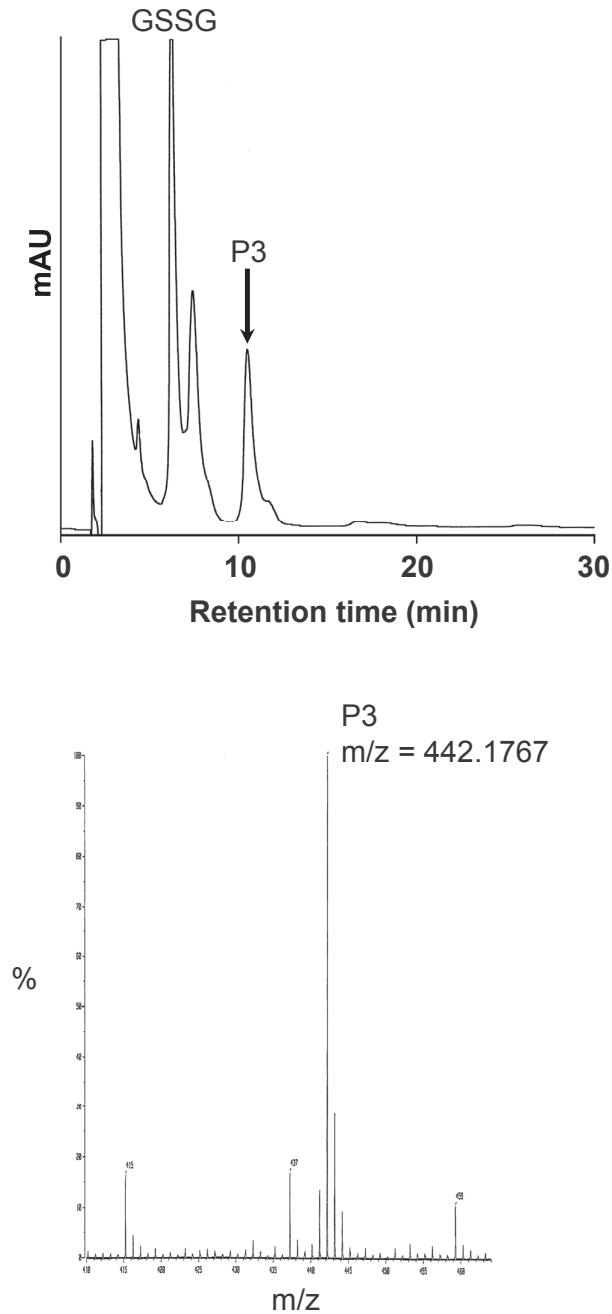

Fig. 2. Analysis of the DHP-GSH conjugates. A, HPLC profiles of the reaction mixtures of Me-DHP-3 (left) and cyclohexyl-DHP (right) with GSH. The reaction and HPLC conditions are described in the Materials and Methods section. B, FAB-MS chromatograms for peaks $\mathrm{P} 1, \mathrm{P} 2$ and $\mathrm{P} 3$. Peaks $\mathrm{P} 1, \mathrm{P} 2$ and $\mathrm{P} 3$ gave pseudo-molecular ion peaks corresponding to $[\mathrm{M}+\mathrm{H}]^{+}$with $\mathrm{m} / \mathrm{z}$ values of $444.1916,444.1917$ and 442.1767 , respectively. 
$41.8\left(\mathrm{CH}_{2}\right), 37.0\left(\mathrm{CH}_{2}\right)^{*}, 32.4\left(\mathrm{CH}_{2}\right), 27.1\left(\mathrm{CH}_{2}\right), 25.1$ $\left(\mathrm{CH}_{3} \times 2\right), 18.7\left(\mathrm{CH}_{3}\right)$. ${ }^{*}$ The same as described for P1.

\section{2-amino-5-((1-((carboxymethyl)amino)- $3-((2,3,4,6,7,8$-hexahydroquinoxalin-5-yl)thio)- 1-oxopropan-2-yl)amino)-5-oxopentanoic acid (P3)}

HRMS-FAB-MS in the positive ionization mode gave $m / z$ : 442.1767 (Calcd for C18H28N5O6S [M+H]+: 442.1760). ${ }^{1} \mathrm{H}$ NMR: $\delta 4.63(\mathrm{dd}, J=7.7,6.3 \mathrm{~Hz}, 1 \mathrm{H})$, $3.98(\mathrm{dd}, J=5.7 \mathrm{~Hz}, 1 \mathrm{H}), 3.93(\mathrm{dd}, J=20.4,6.0 \mathrm{~Hz}$, $2 \mathrm{H}), 3.68(\mathrm{t}, J=4.1 \mathrm{~Hz}, 1 \mathrm{H}), 3.51(\mathrm{dd}, J=13.9,6.3 \mathrm{~Hz}$, $1 \mathrm{H}$, Cys- $\beta$ ), 3.27 (dd, $J=13.9,7.9 \mathrm{~Hz}, 1 \mathrm{H}$, Cys- $\beta$ ), 3.29 $(2 \mathrm{H})^{*}, 2.82(\mathrm{~m}, 2 \mathrm{H}), 2.78(\mathrm{~m}, 2 \mathrm{H}), 2.57(\mathrm{t}, J=7.4 \mathrm{~Hz}$, 2H), 2.18 (hept, $J=6.5 \mathrm{~Hz}, 2 \mathrm{H}$ ), 2.01 (quint, $J=6.2 \mathrm{~Hz}$, 2H). ${ }^{13} \mathrm{C}$ NMR: $\delta 174.3(\mathrm{CO}), 172.7\left(\mathrm{CO}_{2}\right), 171.9\left(\mathrm{CO}_{2}\right)$, $171.8(\mathrm{CO}), 167.2(\mathrm{C}), 144.2(\mathrm{C}), 131.4(\mathrm{C}), 54.3(\mathrm{CH})$, $53.5(\mathrm{CH}), 44.6\left(\mathrm{CH}_{2}\right), 41.8\left(\mathrm{CH}_{2}\right), 39.1\left(\mathrm{CH}_{2}\right)^{*}, 33.0$ $\left(\mathrm{CH}_{2}\right), 32.3\left(\mathrm{CH}_{2}\right), 30.6\left(\mathrm{CH}_{2}\right), 29.4\left(\mathrm{CH}_{2}\right), 27.0\left(\mathrm{CH}_{2}\right)$, $22.4\left(\mathrm{CH}_{2}\right)$. *The same as described for P1.

\section{RESULTS AND DISCUSSION}

We recently reported that DHP derivatives caused decrease in the ratio of GSH/GSSG in human hepatoma HepG2 cells (Ishida et al., 2012). Based on this result, we decided to investigate the nature of the interaction between DHP and GSH, which is the most abundant intercellular thiol compound in eukaryotic organisms. Two DHP derivatives were used for this study, including Me-DHP-3 and Cyclohexyl-DHP (Fig. 1). To allow for the detection of the corresponding DHP-GSH conjugates, $50 \mathrm{mM}$ solutions of the DHP derivatives were incubated with $50 \mathrm{mM}$ GSH in $0.1 \mathrm{M}$ sodium phosphate buffer (pH 7) at $37^{\circ} \mathrm{C}$ for $24 \mathrm{hr}$. The resultant products were analyzed by HPLC and the elusion profiles were monitored by absorbance at $210 \mathrm{~nm}$. As shown in Fig. 2A, the elusion profiles revealed the loss of GSH with a concomitant increase in GSSG. Moreover, the reactions with Me-DHP-3 (mw: 138.21) and cyclohexyl-DHP (mw: 136.19) with GSH (mw: 307.33) led to the formation of new peaks with larger retention times than that of GSSG (P1 and P2, or P3, respectively). Subsequent FAB-MS analysis revealed that $\mathrm{P} 1$ and $\mathrm{P} 2$ gave similar $[\mathrm{M}+\mathrm{H}]^{+}$ peaks with $\mathrm{m} / z$ values of 444.1917 and 444.1617 , respectively, and that $\mathrm{P} 3$ gave an $[\mathrm{M}+\mathrm{H}]^{+}$peak with $\mathrm{m} / \mathrm{z}$ value of 442.1767 (Fig. 2B). Peaks P1 and P2 therefore corresponded to the addition of Me-DHP-3 to GSH, with the two peaks representing different isomeric forms, whereas $\mathrm{P} 3$ corresponded to the addition of cyclohexyl-DHP to GSH. NMR analysis (Fig. 3) of the adducts formed between Me-DHP-3 and GSH revealed the disappearance of one of the two imino methyl signal belonging to the DHP moiety. The HSQC spectra of these adducts revealed the appearance of new olefinic ${ }^{1} \mathrm{~J}_{\mathrm{H} / \mathrm{C}}$ correlations from $\delta_{\mathrm{H}} 7.31$ to $\delta_{\mathrm{C}} 132.0 \mathrm{ppm}$ for $\mathrm{P} 1$, and $\delta_{\mathrm{H}} 7.25$ to $\delta_{\mathrm{C}} 130.1$ ppm for P2. Most notably, the HMBC spectrum of P2 revealed that presence of two ${ }^{3} J_{\mathrm{H} / \mathrm{C}}$ correlations from the exo-methyne proton at $\delta_{\mathrm{H}} 7.25 \mathrm{ppm}$ to the $\beta$-carbon of the cysteine moiety of GSH at $\delta_{\mathrm{C}} 37.0 \mathrm{ppm}$, as well as a carbon belonging to the DHP moiety at $\delta_{\mathrm{C}} 132.1 \mathrm{ppm}$. Furthermore, $\mathrm{HMBC}$ analysis of $\mathrm{P} 3$ revealed a reverse ${ }^{3} J_{\mathrm{H} / \mathrm{C}}$ correlation between the $\beta$-proton of the cysteine moiety at $\delta_{\mathrm{H}} 3.51 \mathrm{ppm}$ and a carbon belonging to the cyclohexyl moiety of Cyclohexyl-DHP at $\delta_{\mathrm{C}} 144.2 \mathrm{ppm}$. These ${ }^{3} J_{\mathrm{H} / \mathrm{C}}$ correlation results therefore provided direct evidence of the formation of a new C-S bond between the thiol group of the cysteine residue and the exo-methyl carbon of the DHP derivative (Fig. 1). The highly reactive nature of the exo-methylene group of DHP has been attributed to its latent enamine functionality, and this result has been confirmed both experimentally and theoretically (Ito et al., 2010). The low energy distribution of the highest occupied molecular orbital (HOMO) on the exo-methylene group of the DHP moiety would allow it undergo nucleophilic addition reactions with various biological thiols, including cysteine and GSH. Cyclohexyl-DHP can also participate in an intramolecular equilibrium to give cyclohexenyl-DHP (Takechi et al., 2009). Based on these data, the chemical structures of these products were determined to be those shown in Fig. 4.

In this study, we have investigated the reaction of several DHP derivatives with GSH and analyzed the resultant products. DHP can be readily oxidized under mild conditions and reaches an unstable state when it donates an electron to another species, such as oxygen dissolved in the system, which can lead to the formation of a superoxide anion (Takeda et al., 2005). DHP was reacted GSH, which is a cysteine-containing tripeptide, and the reaction was observed analytically. The reaction of DHP with GSH led to the rapid oxidation of GSH to give multiple products, which were detected by HPLC analysis (Fig. 2A). Structural analysis of these products suggested that the DHP-GSH adducts were produced by an oxidative dehydrogenation reaction.

GSH, which acts as an antioxidant, is one of the most abundant low-molecular weight thiols in mammalian cells (Bhattacharya et al., 1955). Given that GSH is converted to GSSG following its reaction with ROS, and GSH depletion results in elevated cytotoxicity (Mitchell and Russo, 1987). In our previous study, DHP caused growth inhibition of GSH-deficient bacteria (Takechi et 
The adducts of dihydropyrazine and glutathione

P1<smiles>CC1(C)NC(=C(SCC(NC(=O)CCC(N)C(=O)O)C(=O)NCC(=O)O)[Hg]2=NC3CCCCC2C3)C(C)(C)N1</smiles>

P2

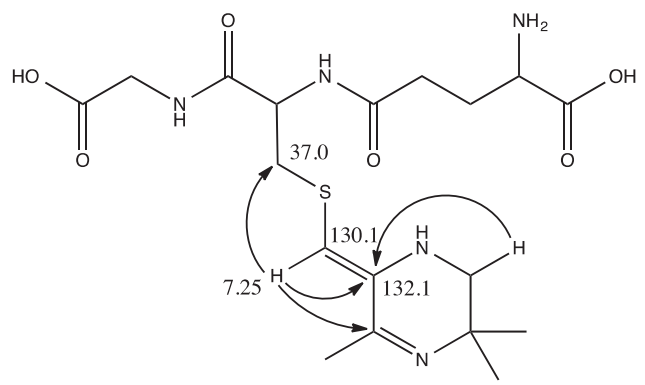

P3

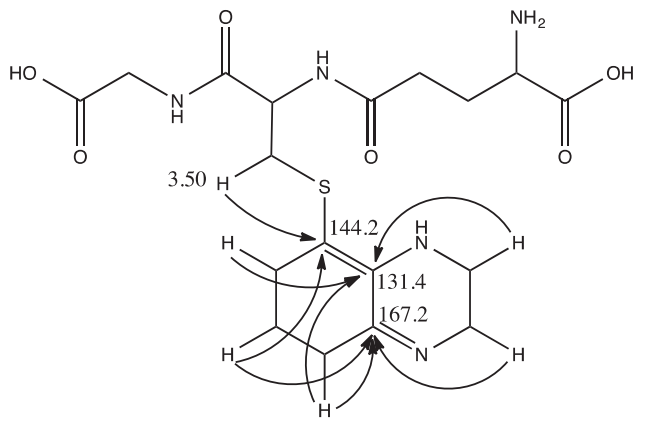

Fig. 3. Significant $\mathrm{HMBC}$ correlations for $\mathrm{P} 1, \mathrm{P} 2$ and $\mathrm{P} 3$.

al., 2011), and DHP also led to a decrease in the ratio of intracellular GSH/GSSG in cultured cells (Ishida et al., 2012). In addition, the exposure of cells to DHP led to the induction of antioxidant gene expression via the activation of the Nrf2-ARE pathway (Ishida et al., 2014).

In conclusion, the results of this study provides further evidence that DHP, as a generator of ROS, oxidizes GSH to give the corresponding DHP-GSH adducts, which results in the depletion of cellular GSH levels. These results therefore suggest that DHP could play a significant role in disrupting metabolic processes in cells, such as disorders associated with oxidative-antioxidative balance.
P1<smiles>CC1=NCC(C)(C)N/C1=C/SCC(NC(=O)CCC(N)C(=O)O)C(=O)NCC(=O)O</smiles>

P2<smiles>CC1=NC(C)(C)CN/C1=C\SCC(NC(=O)CCC(N)C(=O)O)C(=O)NCC(=O)O</smiles>

P3<smiles>NC(CCC(=O)NC(CSC1=C2NCCN=C2CCC1)C(=O)NCC(=O)O)C(=O)O</smiles>

Fig. 4. Structures of the DHP-GSH Conjugates. These structures were deduced from peaks $\mathrm{P} 1, \mathrm{P} 2$ and $\mathrm{P} 3$, as described in the Materials and Methods section.

\section{ACKNOWLEDGMENTS}

This study was supported by a Grant-in-Aid for Scientific Research C (No. 24590169) from the Japan Society for the Promotion of Science. We would like to thank Takahiro Fujimoto, Mami Mamitsuka, Sayaka Taki, Naoki Yahisa, Rise Yamamoto, Ayumi Yamasaki and Ryousuke Yamashita for their valuable assistance.

Conflict of interest---- The authors declare that there is no conflict of interest. 


\section{REFERENCES}

Bhattacharya, S.K., Robson, J.S. and Stewart, C.P. (1955): The determination of glutathione in blood and tissues. Biochem. J., 60, 696-702.

Ishida, T., Takechi, S. and Yamaguchi, T. (2012): Possible involvement of glutathione balance disruption in dihydropyrazine-induced cytotoxicity on human hepatoma HepG2 cells. J. Toxicol. Sci., 37, 1065-1069.

Ishida, T., Yamaguchi, T. and Takechi, S. (2014): The effect of dihydropyrazines on human hepatoma HepG2 cells: a comparative study using 2,3-dihydro-5,6-dimethylpyrazine and 3-hydro-2,2,5,6-tetramethylpyrazine. J. Toxicol. Sci., 39, 601608.

Ito, S., Hirano, T., Sugimoto, A., Kagechika, H., Takechi, S. and Yamaguchi, T. (2010): Latent enamine functionality of 5-Methyl-2,3-dihydropyrazines. Chem. Pharm. Bull., 58, 922-927.

Mitchell, J.B. and Russo, A. (1987): The role of glutathione in radiation and drug induced cytotoxicity. Br. J. Cancer (Suppl.), 55, 96-104.

Takechi, S., Ito, S., Kashige, N., Ishida, T. and Yamaguchi, T. (2011): Glutathione Depression by dihydropyrazine derivative.
J. Toxicol. Sci., 36, 231-235.

Takechi, S, Nakahara, K., Adachi, M. and Yamaguchi, T. (2009): Oxidative stress induced by a dihydropyrazine derivative. Biol. Pharm. Bull., 32, 186-189.

Takeda, O., Takechi, S., Katoh, T. and Yamaguchi, T. (2005): The Role of dihydropyrazines in accelerated death of Escherichia coli on addition of copper(II). Biol. Pharm. Bull., 28, 11611164.

Teixeira, P.C., Onuki, J., Medeiros, M.H., Dörnemann, D. and Di Mascio, P. (2001): DNA damage by 3,6-dihydropyrazine-2,5dipropanoic acid, the cyclic dimerization product of 5-aminolevulinic acid. Biol. Chem., 382, 913-918.

Yamaguchi, T., Kashige, N., Mishiro, N., Miake, F. and Watanabe, K. (1996): Dihydropyrazine derivatives as a new type of DNA strand breaking agent. Biol. Pharm. Bull., 19, 1261-1265.

Yamaguchi, T., Matsumoto, S. and Watanabe, K. (1998): Generation of free radicals from dihydropyrazines with DNA strand-breakage activity. Tetrahedron Lett., 39, 8311-8312.

Zlatkis, A., Bertsch. W., Lichtenstein, H.A., Tishbee, A., Shunbo, F., Liebich, H.M., Coscia, A.M. and Fleischer, N. (1973): Profile of volatile metabolites in urine by gas chromatography-mass spectrometry. Anal. Chem., 45, 763-767. 